\title{
A COMPARATIVE STUDY BETWEEN GENERAL AND SPINAL ANESTHESIA REGARDING MATERNAL BLOOD INDICES CHANGES AFTER LOW RISKY ELECTIVE CEASAREAN SECTION
}

\section{(A PROSPECTIVE CONTROLLED RANDOMIZED STUDY)}

By

\author{
El-Sayed El-Desouky ${ }^{1}$, Osama Kamal Raslan ${ }^{1}$, Ibrahim Abo El-Magd ${ }^{1}$, \\ and Shady M. Hassan ${ }^{2}$ \\ ${ }^{1}$ Department Of Obstetrics and Gynecology, Faculty of Medicine, Al-Azhar University \\ ${ }^{2}$ Department Of anesthesia and ICU, Faculty of Medicine, Zagazig University
}

\begin{abstract}
Background: Delivery by ceasarean section is one of the most common surgical procedures nowadays. However, Choosing of anesthesia is a matter of controversy among obstetrician.

Objective: To study the effect of two types of anesthesia on maternal hemoglobin and hematocrit level after elective cesarean section.

Patients and methods: This was a randomized controlled study done at Sayed Galal University hospital and private centers (Tbarak Private Hospital Group) including 100 pregnant women underwent elective first time ceasarean section for variables causes. Changes in maternal hemoglobin and hematocrit indices were measured.

Result: There was statistically significant difference between both groups after 48th hour post ceasarean section. Mean 48 hours postoperative hemoglobin and hematocrit parameter differences were significantly lower in the group with spinal anesthesia.

Conclusion: Spinal anesthesia was better and has a greater advantage for maternal condition than general anesthesia as regard post-operative blood indices changes. So, whenever it is not contraindicated, spinal anesthesia should be recommended for elective ceasarean section.
\end{abstract}

Key worpsi general and sbinal anesthesia, blood inpices, cesarean.

\section{INTRODUCTION}

Vaginal delivery; the normal route for delivery had been practiced for centuries. However, cesarean section (CS); the surgical alternative for vaginal delivery is gaining popularity due to many indications from both the maternal and fetal points of view Curtin et al., 2013.
Cesarean section is associated with variable degrees of morbidity and mortality due to many risk factors. One of the most important risk factors, are complications related to anesthesia. For long time general anesthesia was recommended and preferred by patients and physicians. But the rate of general 
anesthesia is decreasing with the development of regional anesthesia due to its presumably less risk for mother and the baby in comparison to general anesthesia Wong, 2010.

For CS, the choice of the type of anesthesia is a matter of controversy. General speaking, the choice of the method of anesthesia depends on many factors including the underlying indication of CS, patient desire, and the clinical situation among others Ogboli and Yunus, 2014. General Anesthesia is the best method in case of urgent operation; it may be used when the woman refuses spinal techniques or if failed regional attempts or when regional is contraindicated such as in coagulation disorder or bone deformity in vertebral column Practice guidelines for obstetric anesthesia (2016). There is no complete agreement for the ideal type of anesthesia especially on the field of maternal morbidity and mortality,

The aim of the current study is to compare post-operative hemoglobin and hematocrit values changes between the general and spinal anesthesia among patients with elective first time cesarean section.

\section{PATIENTS AND METHODS}

This study was a prospective controlled clinical study carried out in obstetric department of Sayed Galal university hospital and other private center in Cairo, (Tbarak Private Hospital Group) during the period from January 2019 to November 2019.

It included one hundred patients scheduled for first time elective ceasarean section for variable indications. All patients were pregnant 38 week -40weeks with no any risk factors of pregnancy in singleton cephalic presentation with average sized fetal body weight. Gestational age was calculated by LMP or by documented early ultrasound report.

Complete history, general, and local examination were applied for every patients. Routine laboratory investigation including $\mathrm{CBC}$, hematocrit value, liver and kidney function test, coagulation profile RBS, preoperative medication was including prophylactic antibiotic and $\mathrm{H} 2$ blockers- $500 \mathrm{ml}$ normal saline, exclusion criteria were: patients with high risk pregnancy as twins, macrosomic or IUGR baby, polyhydraminous, hypertensive disorders of pregnancy-cardiac and anemic patients, placenta preavea or accreta.

Written informed consent was taken from every patient for enrollment in this study. Patients were randomly classified into two groups: group A: group of general anesthesia and group B: group of spinal anesthesia. Port -randomization and allocation was done by computer and give Numbers from 1-100 and each number was put in an envelope, one was given to each patient randomly.

All patients received premedication of $0.5 \mathrm{mg}$ atropine sulphate, $10 \mathrm{mg}$ metacloperamide and $50 \mathrm{mg}$ ranitidine. All patients were monitored by ECG, pulseoximetry, capnography and noninvasive blood pressure monitors. In addition to the above monitors, patients in Group A were monitored by neuromuscular stimulation also.

\section{Group A:}

After lying down in supine position with left uterine displacement, patients in 
group A received preoxygenation and their abdomens were prepared and draped before initiation of general anesthesia. Rapid sequence induction was performed with $2.5 \mathrm{mg} / \mathrm{kg}$ propofol and $1.5 \mathrm{mg} / \mathrm{kg}$ suxamethonium, and then patients were intubated with cuffed endotracheal tubes size 7.5. Anesthesia was maintained by sevoflurane inhalation (MAC 2). Oxygen/Nitrous (5/5). $0.5 \quad \mathrm{mg} / \mathrm{kg}$ atracurium and $1 \mathrm{mg} / \mathrm{kg}$ fentanyl were given after delivery of the baby. Ventilation parameters were set to keep end tidal carbon dioxide at $35 \mathrm{mmHg}$. At the end of operation anesthetics were stopped and $0.05 \mathrm{mg} / \mathrm{kg}$ neostigmine with $0.01 \mathrm{mg}$ atropine was given and ETT was removed in awake extubation.

\section{Group B:}

Patients of group B received $500 \mathrm{ml}$ of ringer lactate solution in a period of 15 minutes before anesthesia. Under complete aseptic conditions and local anesthesia at the level of space L3-4 Spinal needle $25 \mathrm{G}$ was used to give intrathecal anesthesia in sitting position and paramedical approach. $2.2 \mathrm{ml}$ hyperbaric Bupivacaine $0.5 \%$ (heavy marcaine) was used with $30 \mathrm{mcg}$ fentanyl. Patients were turned to supine position with left uterine displacement immediately after taking the intrathecal injection. Oxygen was administered via face mask (4 L/min).3 $\mathrm{mg}$ ephidrine increments were used if there is hypotension $(20 \%$ decrease below baseline readings).30 $\mathrm{mg}$ pethidine was used in case of shivering.

After anesthesia and through Pfannensteil incision ceasarean sections were done, utertonic medication given to all patient including oxytocine and methergine, then closure of the uterus in 2 layers using closure of anterior abdominal wall in separate layers, all cesarean sections were done by same group of experienced physicians, hemoglobin ( $\mathrm{g} / \mathrm{dl})$ and hematocrit (Hct,) values (\%) were determined both group before and at the 48 th hour postoperatively.

\section{Statistical Analysis:}

Statistical analysis were performed using SPSS (SPSS Inc., Chicago, Illinois, USA) and described as the mean \pm SD, frequency, and percentage. Student's ttest was used for continuous variables. Statistical significance was defined as $\mathrm{P}$ value less than 0.05 .

\section{RESULTS}

\section{Patient characteristics:}

One hundred pregnant women in singleton cephalic presentations with average sized fetal body weight were scheduled for first time non risky elective ceasarean section for variable indications. The mean ages were $27.3 \pm 5.3$ years, range: 18-36years. There was no statistically significant difference between general anesthesia group and spinal anesthesia group as regards maternal age, gestational age, BMI, duration of surgery (Table 1). 
Table (1): Comparison of both groups as regard Demographic data

\begin{tabular}{|c|c|c|c|c|}
\hline \multicolumn{2}{|l|}{ Parameters } & $\begin{array}{c}\text { Group A } \\
\text { general } \\
\text { anesthesia } \\
(\mathbf{n}=\mathbf{5 0})\end{array}$ & $\begin{array}{c}\text { Group B } \\
\text { spinal } \\
\text { anesthesia } \\
(\mathbf{n}=\mathbf{5 0})\end{array}$ & p-value \\
\hline \multirow[b]{2}{*}{ Age (years) } & Mean \pm SD & $27.2 \pm 4.2$ & $27.4 \pm 3.2$ & \multirow[b]{2}{*}{$>0.05$} \\
\hline & $\begin{array}{l}\text { Minimum- } \\
\text { maximum }\end{array}$ & $18-36$ & $19-35$ & \\
\hline \multirow{2}{*}{$\begin{array}{c}\text { Gestational age } \\
\text { (weeks) }\end{array}$} & Mean \pm SD & $38.8 \pm 0.5$ & $38.8 \pm 0.8$ & \multirow{2}{*}{$>0.05$} \\
\hline & Range & $38-40$ & $38-40$ & \\
\hline \multirow{2}{*}{ BMI $\left(\mathrm{Kg} / \mathbf{M}^{2}\right)$} & Mean \pm SD & $25.2 \pm 2.3$ & $26.1 \pm 2.4$ & \multirow{2}{*}{$>0.05$} \\
\hline & Range & $21-31$ & $20-30$ & \\
\hline
\end{tabular}

BMI: body mass index

\section{Operative details:}

There was no statistical difference between both group as regard operation and recovery duration, preoperative and intra-operative blood pressure but it was noticeable that there was a little drop in intra- operative systolic blood pressure among patents under spinal anesthesia.

\section{Laboratory and clinical parameters:}

The mean 48th hours postoperative hemoglobin level was $(8.11 \pm 1.12 \mathrm{vs} 9.82+1.15 \mathrm{~g} / \mathrm{dl})$, and The mean 48th hours postoperative hematocrit level was $(27.07 \pm 2.84 \mathrm{vs} 31.68+3.85 \%$ $\mathrm{p}=0.09$ and 0.8 respectively) in group A vs. group $\mathrm{B}$, whereas the 48th hour hemoglobin difference values Was $(1.4+0.3$ vs. $4.05+0.2 \mathrm{~g} / \mathrm{dl}) \quad(\mathrm{P}=0.03)$, whereas the 48th hour hematocrit difference values Was $(4.4 \pm 1.12$ vs. $3.5+1.05 \%, \mathrm{p}=0.02$ ) which is statistically higher in group A. but there was no significant differences between both group as regard pulse and blood pressure changes (Table 2). 
Table (2):

\begin{tabular}{|c|c|c|c|c|}
\hline \multicolumn{2}{|l|}{ Parameters } & $\begin{array}{c}\text { Group A } \\
\text { general } \\
\text { anesthesia } \\
(\mathbf{n}=50)\end{array}$ & $\begin{array}{c}\text { Group B } \\
\text { spinal } \\
\text { anesthesia } \\
(n=50)\end{array}$ & $\begin{array}{c}\text { P-value } \\
\text { Mann } \\
\text { Whitney } \\
\text { test }\end{array}$ \\
\hline \multirow{9}{*}{ HCT (\%) } & Preoperative & & & \multirow{3}{*}{$>0.05$} \\
\hline & Mean \pm SD & $33.47 \pm 3.99$ & $34.10 \pm 3.25$ & \\
\hline & Range & $25-43$ & 27.1-48.1 & \\
\hline & Postoperative & & & \multirow{3}{*}{$<0.001$} \\
\hline & Mean \pm SD & $27.07 \pm 2.84$ & $31.68 \pm 3.85$ & \\
\hline & Range & $21.1-34.5$ & $24.2-41.2$ & \\
\hline & 48 th difference & & & \multirow{3}{*}{$<0.001$} \\
\hline & Mean \pm SD & $4.4 \pm 1.12$ & $3.5 \pm 1.05$ & \\
\hline & Range & 2.8-6.4 & $1.5-6.1$ & \\
\hline \multirow{9}{*}{$\mathrm{Hb}(\mathrm{g} / \mathrm{dl})$} & Preoperative & & & \multirow{3}{*}{$>0.05$} \\
\hline & Mean \pm SD & $10.25 \pm 2.21$ & $11.03 \pm 1.13$ & \\
\hline & Range & $8.5-15$ & $8.5-14.2$ & \\
\hline & Postoperative & & & \multirow{3}{*}{$<0.001$} \\
\hline & Mean \pm SD & $8.11 \pm 1.12$ & $9.82 \pm 1.15$ & \\
\hline & Range & $6.5-11.9$ & 6.9-13.1 & \\
\hline & 48 th difference & & & \multirow{3}{*}{$<0.001$} \\
\hline & Mean+SD & $1.4 \pm 0.3$ & $1.05 \pm 0.2$ & \\
\hline & Range & $1-2$ & 0.8-1.4 & \\
\hline \multirow{2}{*}{$\begin{array}{c}\text { Amount of } \\
\text { blood loss } \\
(\mathrm{ml})\end{array}$} & Mean \pm SD & $1215.17 \pm 320.58$ & $914.14 \pm 325.65$ & \multirow[b]{2}{*}{$<0.001$} \\
\hline & Range & 588.8-1986.8 & $554-1702.3$ & \\
\hline \multirow{6}{*}{$\mathbf{S B P}(\mathrm{mm} \mathrm{Hg})$} & Preoperative & & & \multirow{3}{*}{$>0.05$} \\
\hline & Mean \pm SD & $124.31 \pm 8.55$ & $110.81 \pm 9.74$ & \\
\hline & Range & $110-140$ & $100-130$ & \\
\hline & Postoperative & & & \multirow{3}{*}{$>0.05$} \\
\hline & Mean \pm SD & $108.88 \pm 10.58$ & $107.00 \pm 10.74$ & \\
\hline & Range & $85-135$ & $85-125$ & \\
\hline \multirow{6}{*}{$\begin{array}{l}\text { Pulse rate } \\
\text { (beats/min) }\end{array}$} & Preoperative & & & \multirow{3}{*}{$>0.05$} \\
\hline & Mean \pm SD & $88.83 \pm 9.73$ & $90.45 \pm 5.63$ & \\
\hline & Range & $78-108$ & $75-121$ & \\
\hline & Postoperative & & & \multirow{3}{*}{$>0.05$} \\
\hline & Mean \pm SD & $99.52 \pm 7.2$ & $98.08 \pm 7.42$ & \\
\hline & Range & $80-120$ & $82-112$ & \\
\hline \multirow{6}{*}{$\begin{array}{c}\text { DBP }(\mathrm{mm} \\
\mathrm{Hg})\end{array}$} & Preoperative & & & \multirow{3}{*}{$>0.05$} \\
\hline & Mean \pm SD & $71.00 \pm 5.04$ & $70.63 \pm 5.56$ & \\
\hline & Range & $60-95$ & $56-95$ & \\
\hline & Postoperative & & & \multirow{3}{*}{$>0.05$} \\
\hline & Mean \pm SD & $67.88 \pm 6.25$ & $68.54 \pm 9.61$ & \\
\hline & Range & $50-85$ & $55-85$ & \\
\hline
\end{tabular}

Hct: heamtocrit- Hb: hemoglobin -SBP: systolic blood pressure- DBP: diastolic blood pressure 


\section{DISCUSSION}

Despite the fact that ceasarean section is a relatively safe procedure, increasing ceasarean section rate is a cause for concern to obstetricians and anesthetists because of the increased health risks Yeoh et al., 2010. Ceasarean section still has a higher maternal morbidity and mortalities more than vaginal deliveries due to many risks. One of which is the risk of different types of anesthesia Ogboli and Yunus, 2014

Until now there is no agreement about the ideal ceasarean section technique or the safest anesthesia that should be given in caesarean section. However, the experiences of physicians and the trends are shifted towards spinal anesthesia in last decades especially for the sake of maternal outcomes. Reynolds, 2010 and this is shown in the current study where $50 \%$ of our patients operated with spinal anesthesia.

One of the most important issues related to the type of anesthesia during caesarean section is the amount of blood loss and this have long been discussed in the literature. But how this blood loss could be estimated? The answer came after Bourke and Smith, 1974 who proposed an equation to estimate the blood losses using preoperative and 48th hour postoperative hematocrit values and that is why both hematocrit and hemoglobin levels were used in the current study. It seems from many reports, including results of the current study that the blood loss was significantly more in general Anesthesia group compared to spinal Anesthesia group Afolabi and Lesi, 2012 and Martin et al., 2014.
One large meta-analysis carried out by Afolabi and Lesi, 2012 found that, the amount of blood loss during ceasarean section under general anesthesia is higher than it in ceasarean section under spinal anesthesia. They included various types of patients; elective and emergency, first time and previous sections, and both low and high risk and with variable indications for caesarian section. The authors attributed these findings to some uterine relaxant effects of some medication used in ceasarean section. Another interesting study by Ezzatalsad at et al., 2013 that included obstetric emergency caesarian section found that the mean loss of hemoglobin in terms of mean hemoglobin differences and hematocrit differences in spinal anesthesia group was significantly lower than general anesthesia group postoperatively, results that are consistent with our results.

The findings that blood loss in patients operated under general anesthesia is more than blood loss in patients operated under spinal anesthesia is reported not only in the international literature Afolabi and Lesi, 2012, Jeong et al., 2012, Martin et al., 2014.

But also from the Egyptian local community, where Abdalla and AbdelRahman, 2015 studied 100 Egyptian women randomly allocated for their caesarian section to either general $(n=50)$ or spinal $(\mathrm{n}=50)$ anesthesia and they found that a reduction in mean hemoglobin level in general anesthesia group is more than in spinal anesthesia group on $3^{\text {rd }}$ day postoperative. Moreover, there was a reduction in mean hematocrit value in general anesthesia group more than that of 
spinal anesthesia group on 3rd day postoperatively.

Another important parameter studied in the current study is the blood hemodynamic (blood pressure and pulse rate) during the surgery and there was no statistical difference between both groups as regard preoperative and intra-operative blood pressure but it was noticeable that there was little drop in intra-operative systolic blood pressure in patents under spinal anesthesia. In a study by Saygl et al., 2015, intra-operative drop of blood pressure occurred in $26 \%$ of spinal cases.

In our study, there was no statistical difference between both group as regard pre and intra-operative pulse rate, in other study, it was noticed significant increase in pulse rate in patient with general anesthesia than in spinal anesthesia, this was attributed to delay in analgesic drugs in general anesthesia which was routinely postponed until delivery of the baby, and due to stress of induction of general anesthesia (Abdallah et al., 2014).

\section{CONCLUSION}

When compared with general anesthesia, spinal anesthesia seems better regarding post-operative blood loss represented by significantly lower drops of hemoglobin and hematocrit and, whenever it is not contraindicated, it could be an ideal choice for low risk, first time elective caesarean section.

\section{REFERENCES}

1. Abdalla MA and Abdel-Rahman MA (2015): The effect of general compared to spinal anesthesia on blood loss in cesarean section a randomized controlled study vol 13 , no 2 , suppl 2:111-116.
2. Abdallah MW, Elzayyat NS, Ahmed MA, and Gado AM. (2014): Comparative study of general anesthesia versus combined spinal-epidural anesthesia on the fetus in cesarean section. Egypt J Anaesth; 30:155-160.

3. Afolabi BB, and Lesi FE. (2012): Regional versus general anesthesia for caesarean section. Cochrane Database Syst Rev; 10:CD004350.

4. Bourke DL, and Smith TC. (1974): Estimating allowable hemodilution. Anesthesiology; 41:609-611.

5. Curtin SC, Gregory KD, Korst LM, and Uddin SF. (2015): Maternal morbidity for vaginal and cesarean deliveries, according to previous cesarean history: New data from the birth certificate, Natl Vital Stat Rep; 64:1-13.

6. Ezzatalsadat J, Shamsi N, Aamir J, and Omid M (2013): Comparison of hematocrit concentration after cesarean section between two methods: general anesthesia Vs spinal anesthesia. Life Science Journal, 9(4):1258-60.

7. Incerpi MH. (2013): Operative delivery. In: Decherney AH, NathanL, Laufer N, Roman A, editors. Diagnosis and Treatment, Obstetricsand Gynecology $11^{\text {th }}$ ed. New York, USA: McGraw-Hill, Company Incorporated; p. 334-48.

8. Jeong K, Hyang L, Eun K, and Myung W. (2012): The effect of type of anesthesia on intra and postoperative blood loss at elective cesarean section Korean Journal of anesthesiol., 62(2): 125-129.

9. Martin TC, Bell P, and Ogunbiyi $O$ (2014): Comparison of general anesthesia and spinal anesthesia for caesarean section in Antigua and Barbuda. West Indian Medical Journal, 56:4.

10.Ogboli-Nwasor E, Yunus AA. (2014): Anesthesia for cesarean deliveryin a 
low-resource setting, an initial review. Open J Anesthesiol; 4: 217-22.

11.Practice guidelines for obstetric anesthesia (2016): An updated reportby the American Society of Anesthesiologists Task Force on Obstetric Anesthesia and the society for obstetric anesthesia and perinatology.

Anesthesiology; 124:270-300.

12.Reynolds F (2010): General anesthesia is unacceptable for elective cesarean section. Int J Obstet Anesth; 19:212-217.

13.Saygı Aİ, Özdamar Ö, Gün İ, Emirkadı H, Müngen E, and Akpak YK (2015): Comparison of maternal and fetal outcomes among patients undergoing cesarean section under general and spinal anesthesia. Sao Paulo Med J; 133:227234.

14.Wong CA. (2010): General anesthesia is unacceptable for elective cesarean section. Int J Obstet Anesth; 19: 209-212.

15.Yeoh SB, Leong SB, and Heng AS. (2010): Anaesthesia for lower-segment caesarean section: Changing perspectives. Indian J Anaesth 54:409-14. 


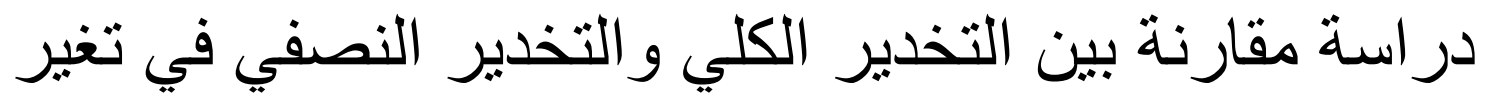

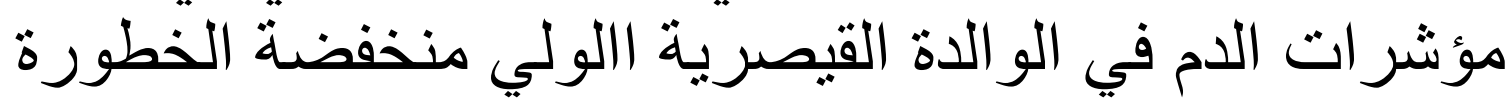

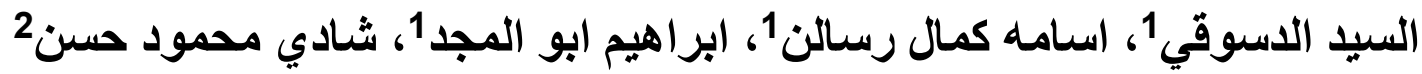

1 - 2قسم النساء والتوليد، كلية الطب، جامعة الأزهر

2ققسم التخدير والرعاية المركزة، كلية الطب، جامعة الزقازيق

E-mail: afathyneuro@gmail.com

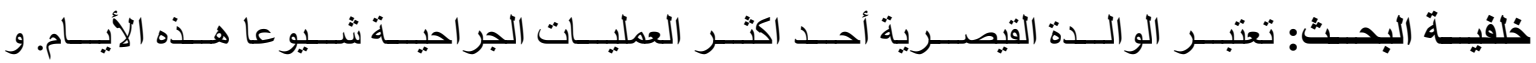

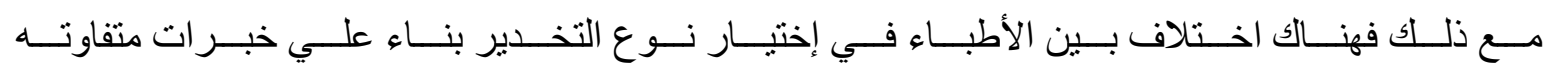

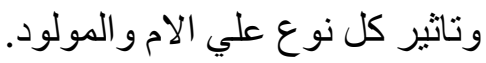

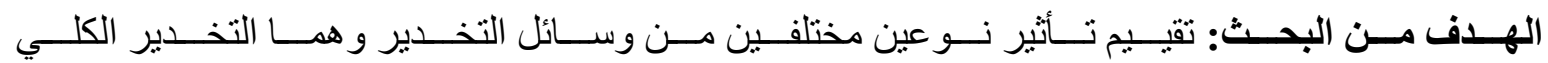

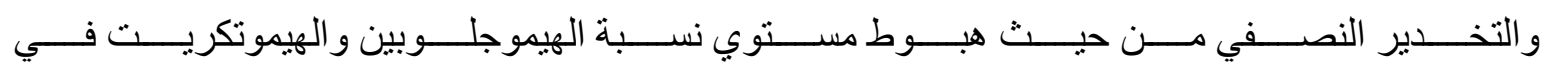
السيدات اللو اتي خضعن للو لادة القيصرية.

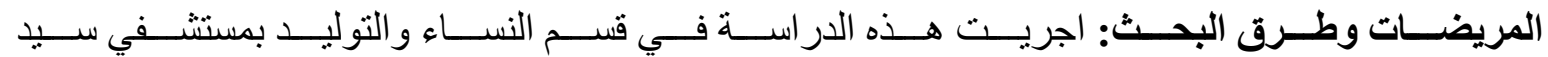

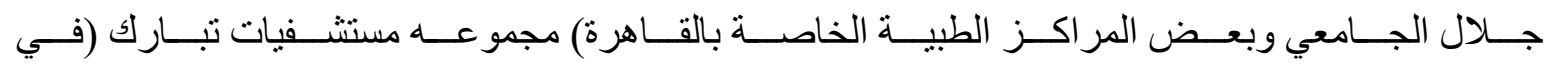

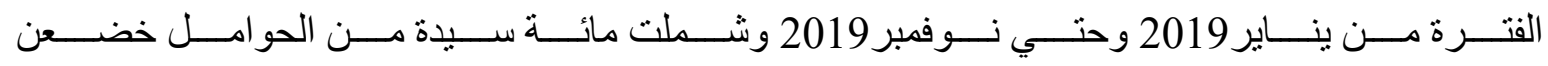

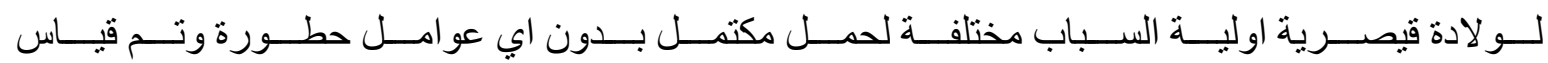
نسبة الهيموجليين و الهيموتكريت قبل العملية وبعد 48 ساعة من الو لادة.

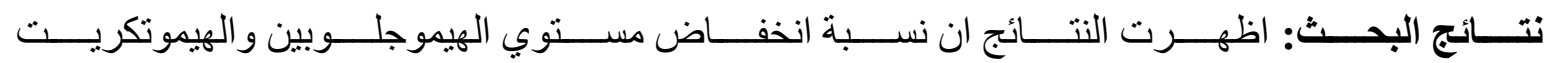

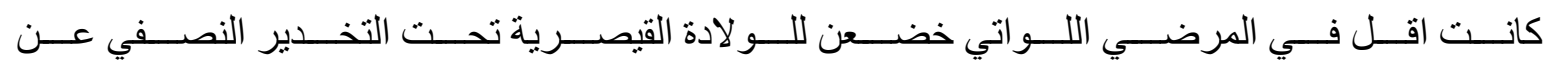
مثيالتها من المرضي اللو اتي خضعن للو لادة القيصرية تحت التخدير الكلي.

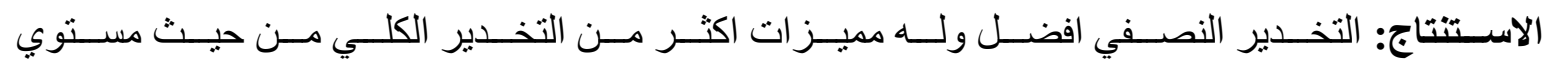

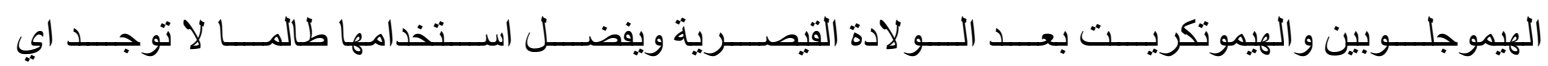

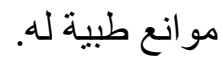
الكلمات الالةة: التخدير الكلى و النصفى ـ دلالات الدم - القيصرية . 